Dhaka Univ. J. Biol. Sci. 25(2): 149-159, 2016 (July)

\title{
IDENTIFICATION OF MEGASELIA SCALARIS (DIPTERA : PHORIDAE) BASED ON MORPHOLOGY AND MITOCHONDRIAL 16S rRNA AND COI GENE SEQUENCES
}

\author{
Mohammad Shamimul Alam*, Khandaker Asif Ahmed, \\ Rowshan Ara Begum and ReZa M Shahjahan \\ Department of Zoology, University of Dhaka, Dhaka-1000, Bangladesh
}

Key words: Megaselia scalaris, Identification, PCR-sequencing, 16S rRNA, COI gene

\begin{abstract}
Megaselia scalaris (Diptera: Phoridae), commonly known as scuttle fly, is widely distributed all over the world. It is easily cultured in the laboratory condition making it a potential model organism. Besides, it has forensic importance. However, no report from Bangladesh could be retrieved about this fly. So, in the present study, identification of this species was attempted using both morphological and molecular approaches. Characteristics of male hypopygium and legs played key roles in morphological identification. To strengthen identification, mitochondrial COI and 16S rRNA gene fragments were amplified and sequenced. Blast search at NCBI provided highest hits to available COI and $16 \mathrm{~S}$ rRNA sequences of $M$. scalaris. A neighbor joining phylogenetic tree was built using sequences of respective COI gene region to show its relationship among other closely related dipteran flies.
\end{abstract}

\section{Introduction}

Megaselia scalaris (Loew 1866) (Diptera : Phoridae) is a cosmopolitan, forensically important fly with a broad ecological habits(1). They are mainly found in warm climate regions with higher latitudes(2). This fast moving, brownish fly shows a unique humpbacked structure on thorax, with hair-like processes, located between the facets of the compound eye ${ }^{(3)}$. The larvae of $M$. scalaris have been described as detritivore, parasite, parasitoid and facultative parasites (myiasis agents) of vertebrates, including human, and consume a wide range of organic materials ${ }^{(4)}$. Adult $M$. scalaris has been reported as a polyphagous organism, generally acting as saprophagous, sarcophagous or necrophagous $^{(4-6)}$. Because of their voracious feeding habit, they can be easily maintained in laboratory condition(4-5).

Several reports have been published around the world about occurrence of this human associated fly. M. scalaris is found in North America, Asia, Africa and Europe ${ }^{(6-9)}$, even on remote islands, like, Boatswainbird, Canary and Galápagos Islands(10-12). But, no record is found from Bangladesh.

*Author for correspondence: <shamimul@du.ac.bd>. 
For species identification, DNA sequencing is currently the most widely used method ${ }^{(13)}$. The process includes comparing genomic sequences of a target sample with a comprehensive reference database. For genomic sequence analysis, both mitochondrial and nuclear gene sequences are commonly used(14,15). Saccone et al. 1999 has preferred mitochondrial genome than nuclear genome because of its lack of introns, limited exposure to recombination and haploid mode of inheritance ${ }^{(16)}$. Mitochondrial genes, such as, Cytochrome oxidase 1 (COI), $16 \mathrm{~S}$ and $12 \mathrm{~S}$ rRNA are commonly used for identification purposes ${ }^{(17)}$. The objective of the present study has been identification of Megaselia species based on morphology and sequences of two mitochondrial genes, $16 \mathrm{~S}$ ribosomal RNA (16S) and cytochrome coxidase 1 (COI) as the first attempt from Bangladesh.

\section{Materials and Methods}

The fly was collected from yeasted banana bait, generally used for collection of Drosophila flies. Collection site was Khilgaon, situated in the middle of Dhaka, Bangladesh and collection was made between January and February, 2015. The flies were reared in fly vials with semolina-agar-dextrose-yeast medium. To get isofemale population, male and female flies were separated and pairs were isolated and cultured. After two generations, flies were morphologically identified and some of them were used for molecular analysis.

A well-accepted key to this genus was provided by Disney, 1994(18). The most recent keys to those of Europe, Galápagos Islands and Canary Islands were also provided by Disney ${ }^{(4,6,10-12,18)}$. All available keys were utilized for the identification of Megaselia flies.

Genomic DNA was extracted from 5 - 6 whole flies by CTAB DNA extraction protocol ${ }^{(19)}$ with slight modification. The modifications include additon of $4 \mu \mathrm{l}$ proteinase $\mathrm{K}$ to the sample before incubation for protein degradation and use of phenol-chloroformisoamyl alcohol (25:24:1) instead of chloroform-isoamyl alcohol for purification. Precipitated DNA was dissolved in $50 \mu \mathrm{l}$ sterilized distilled water and visualized in $1 \%$ agarose gel with a positive control of Drosophila melanogaster DNA sample.

DNA fragments of the mitochondrial 16 rRNA and cytochrome oxidase 1 (COI) genes were amplified using the oligonucleotide primers listed in Table 1. PCR amplifications were performed in $50 \mu \mathrm{l}$ using $5 \mu \mathrm{l}$ 10X PCR reaction buffer, $5 \mu \mathrm{l} 25 \mathrm{M} \mathrm{MgCl}_{2}, 1 \mu \mathrm{l} 10 \mathrm{mM}$ $\mathrm{dNTP}, 0.5 \mu \mathrm{l}$ forward primers, $0.5 \mu \mathrm{l}$ reverse primers, $0.5 \mu \mathrm{l}$ Taq DNA polymerase (Thermo Scientific USA; Cat. EP0402) and $3.5 \mu$ template DNA. Rest volume was filled using sterilized distilled water. The thermal cycling profiles that were programmed to amplify the gene by PCR for 30 cycles are as follows: $95^{\circ} \mathrm{C}, 2 \mathrm{~min}$ for initial denaturation; $95^{\circ} \mathrm{C}, 2 \mathrm{~min}$ for denaturation; $53^{\circ} \mathrm{C}, 1 \mathrm{~min}$ for annealing $16 \mathrm{~S}$ rRNA primers or $57^{\circ} \mathrm{C}$ for annealing COI primers; $72^{\circ} \mathrm{C}, 1 \mathrm{~min}$, for elongation and $72^{\circ} \mathrm{C}, 5 \mathrm{~min}$ for final elongation.

Finally, PCR products were held at $22^{\circ} \mathrm{C}$. PCR products were detected by agarose gel 
electrophoresis. Amplified DNA fragments were then purified using Favor Prep PCR cleanup Mini kit (Favorgen Biotech Corp.).

Table 1. Oligonucleotide primers used in this study.

\begin{tabular}{lll}
\hline Primer name & Sequence $(5 \rightarrow 3)$ & Reference \\
\hline 16S rRNA - F & CGCCTGTTTAACAAAAACAT & Palumbi 1996 \\
16S rRNA - R & CCGGTTTGAACTCAGATCATG & Palumbi 1996 \\
COI F & GGTCAACAAATCATAAAGATATTGG & Folmer et al. 1994 \\
COI R & TAGACTTCTGGGTGGCCAAAGAATCA & Ward et al. 2005 \\
\hline
\end{tabular}

PCR products were directly sequenced in both directions by Sanger Dideoxy Sequencing method in the Centre for Advanced Research in Sciences (CARS), University of Dhaka, Dhaka. Sequence chromatograms were read using FINCH TV software. Sequences of forward and reverse DNA strands were then edited and aligned manually using SEAVIEW software.

MEGA6 ${ }^{(20)}$ and SEAVIEW(21) were used for sequence analysis. Blast searches at NCBI were performed for species identification. For multiple sequence alignment, complete COI gene sequences of some dipteran insects were collected from NCBI and their list is shown in Table 2. Sequences were aligned using CLUSTAL $W^{(22)}$. For phylogenic analysis, MEGA6 and SEAVIEW were used. A neighbor-joining ${ }^{(23,24)}$ tree was constructed using MEGA6 to observe phylogenetic relationships of this fly with other dipteran genus. For protein coding nucleotide sequences, genetic code was selected for "invertebrate mitochondrial" and number of bootstrap replicons was set to 100 .

Table 2. A list of COI gene sequences collected from NCBI database for present study.

\begin{tabular}{ll}
\hline Species & Accession number \\
\hline Calliphora vicina & NC_019639 \\
C. vomitoria & NC_028411 \\
Drosophila ananassae & BK006336 \\
Haematobia irritans & NC_007102 \\
Lucilia cuprina & NC_019573 \\
Musca domesticus & KM200723 \\
Muscina stabulans & NC_026292 \\
Tribolium castaneum & KM009121 \\
Sarcophaga albiceps & NC_028413 \\
Sarcophaga impatiens & NC_017605 \\
\hline
\end{tabular}

\section{Results and Discussion}

Before molecular analysis, the fly was morphologically identified as M. scalaris. It belongs to the family Phoridae and order Diptera of the phylum Arthropoda. Characteristic features of the fly are presented in Figs 1, 2. 
Males or females with wings (Fig. 1A); mid-tibia without paired bristles; hind tibia with a dorsal hair palisade (Fig. 1A); clearly forked vein 3 of wings.

Frons brownish yellow; halter knob yellowish; prothorax brown dorsally, scutellum pale brownish yellow (Fig. 1A); pleural regions mainly pale yellowish, but browner dorsally (Fig. 1D); abdominal tergites dark brown with yellow markings; legs long, dusky pale yellow in color; brownish veins and greyish brown membrane on wings.
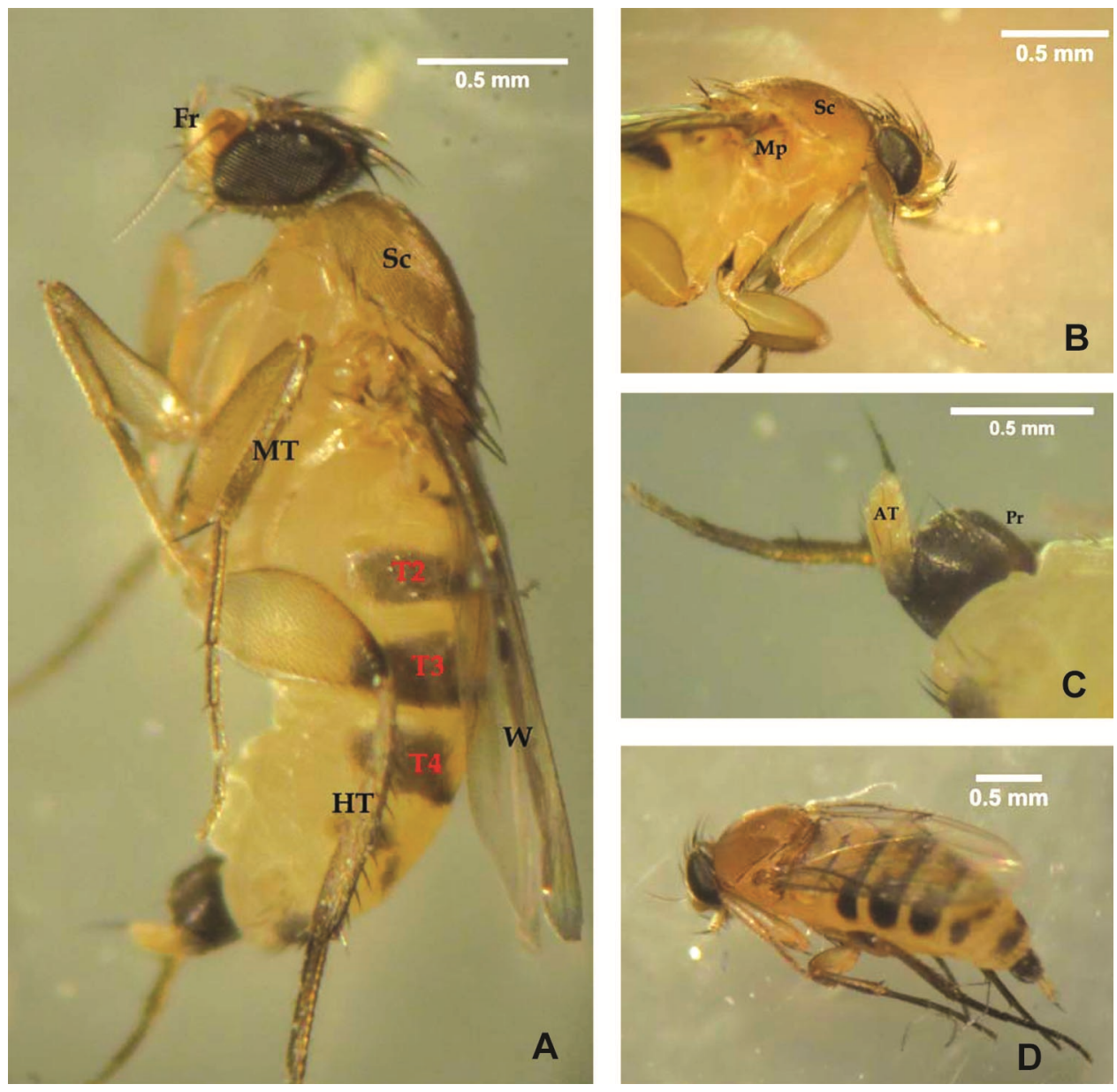

Fig. 1. Megaselia scalaris male. (A) Right face of whole body. (B) Left face of notopleuron. (C) Left wing.

(D) Left face of hypogeum. (E) Dorsal surface of the body. (Fr- Frons. Sc - Scutellum. MT - Mid Tibia. T2, T3 and T4 - Tergites 2, 3 and 4. HT - Hind Tibia. W - Wing. MP - Mesopleuron. AT - Anal Tube. Pr - Proctiger).

Male fly is robust; feathered seta present at tip of proctiger, clearly longer and thicker than setae on circus; mesopleuron naked without any hairs or bristles (Fig. 1B). A short row of four or five spine-like bristles present, with bent over tips on hypogeum, rather beneath base of hind femur. Hairs at tip of anal tube not differentiated (Fig. 1C). 
Female is more distinctive than male; mesopleuron with hairs only, without bristles; palps straw yellow; no hair at base of vein 3; each labellum with fewer than 20 small spinules on lower face; tergites partly yellow; abdominal tergite 6 short and extremely broad; T3 and T4 tergites broader than T5 (Fig. 2A); T6 clearly broader than T5; scutellum with four bristles.
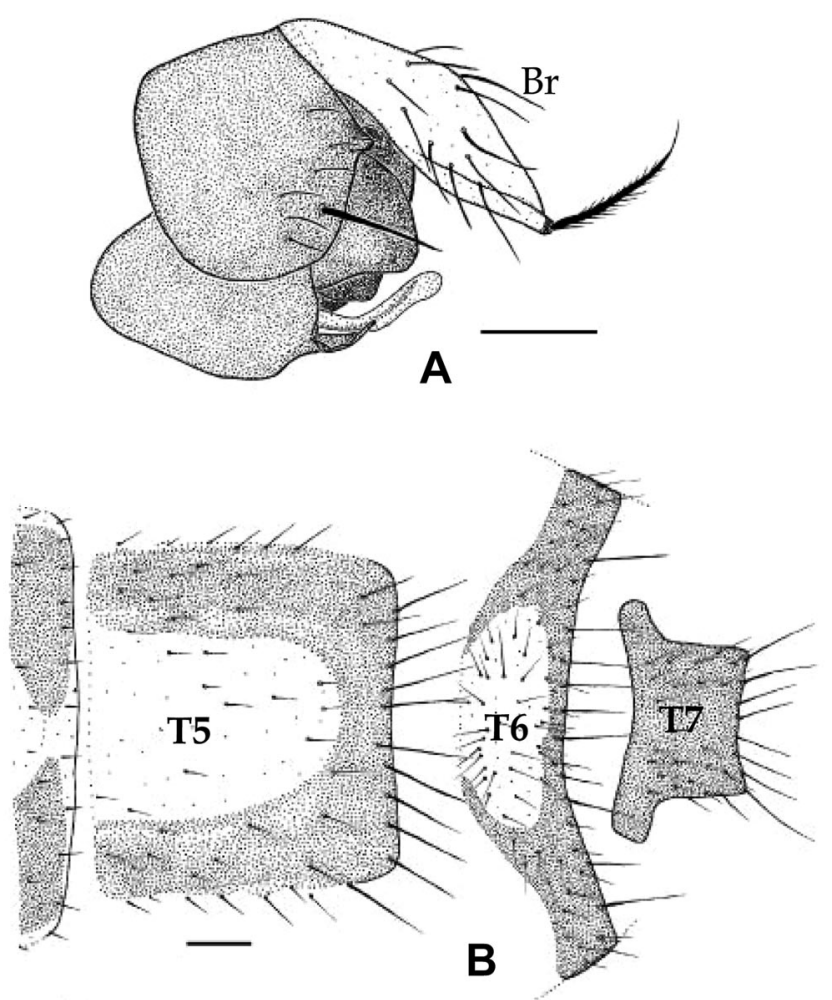

Fig. 2. Megaselia scalaris. (A) Left face of male hypopygium. (B) Female abdominal tergites 5 - 7. (Adapted from Disney et al. 2010) (Br- Bristles. T5, T6 and T7 - Tergites 5, 6 and 7).

Representative gel images of extracted DNA and amplified fragments of interests (mt $16 \mathrm{~S}$ rRNA and COI) are presented in the Fig. 3.

Sequences are provided in Tables 3 and 4.

BLAST search of the 16S rRNA and COI gene sequences at NCBI returned highest query coverage ( $93 \%$ for $16 S$ and $98 \%$ for COI gene) with $M$. scalaris.

The evolutionary history was inferred using the Neighbor-Joining method. The analysis involved 12 nucleotide sequences of COI gene of different dipteran flies. The evolutionary distances were computed using the Maximum Composite Likelihood method. All positions containing gaps and missing data were eliminated. There were a total of 560 positions in the final dataset. 
Though molecular tools are being used in species identification nowadays, gene sequences of many species are still not available in the sequence databases. As a result, exact identification is not possible just by comparing sequences of an unknown organism with those available in the databases. So, identification using morphological keys plays important role before attempting a molecular approach. Genus Megaselia of phorid family

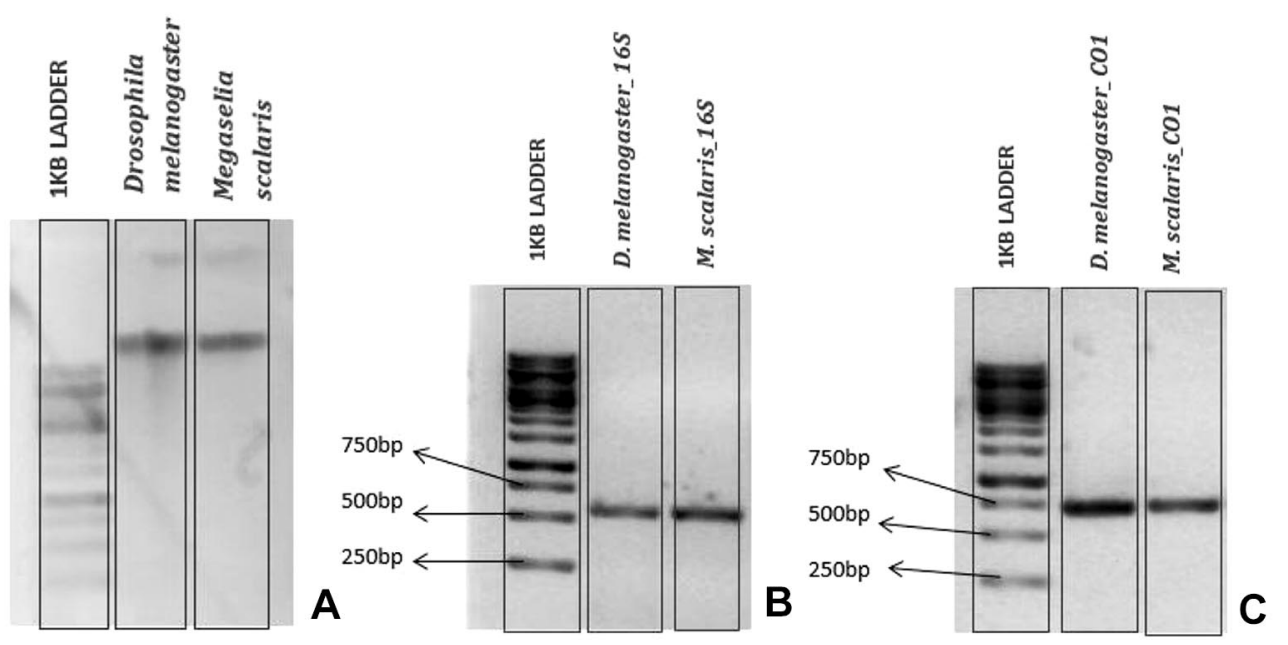

Fig. 3. Extracted DNA of Drosophila melanogaster and Megaselia scalaris (A), PCR products of $16 \mathrm{~S}$ rRNA (B) and COI gene (C) regions of both species, all visualized in $1 \%$ agarose gel. D. melanogaster sample was used as a positive control.

Table 3. Partial sequences of 16S rRNA gene determined in the present study.

>16S rRNA_Partial_,$M$. scalaris
TTTTATTTATGGCTGCAATATCTTAATGTGCAAAGGTAGCATAATCATTAATCTGAAATTGAGGG
CTGGTATGAATGGTTGGATGAAATATTAACTGTTTTAAATAAATTTATAATAGAATTTTATTTTTT
AGTTATAAAGCTAAAATAATTTAAAAGACGAGAAGACCCTATAGAAAAATCTTTATATATAAGTT
ATTTTAATTATATAGATAAAAATTAAATTATTATAAATTTATATATTTTATTGGGGTGATATTAAAAT
TTGTTAAATTTTTAATTCTATAATAAAACATAAATTAATGAATTATTGATCCATTAATTAATGATTA
AAAAATCAAGTTACTTTAGGGATAACAGCGTAATTTTTTAGAGAGTTCTTTTTGATAAAAAA
GACTGCCCCCCTTGATGTTTGGATTAAGATACAGTTTTTAGGTGCAGCAGCTTAAACTTAAAGT
CTGTTCCGACTTTTTAAATTCTTACATGATCTGAGTTCCAAACC $=\mathbf{5 0 3 b p}$

includes around 1,400 species of flies distributed in tropical and subtropical areas(6,25-26). Among the species of this genus, only a few has been represented in the sequence databases. So, the existing morphological keys to Megaselia species have been enormously valuable prior to molecular identification.

Features of male hypopygium are mainly used in morphological identification of Megaselia species ${ }^{(4,25)}$. Male M. scalaris are closely related with M. longiseta and M. rufipes in the keys of Megaselia species of canary island(11). A short row of four or five spine-like bristles generally occur beneath the base of hind femur of $M$. longiseta with different 
hypopygium structure, which are not observed in $M$. scalaris. Morever, M. scalaris possess feathered bristles at the tip of anal tube, which $M$. rufipes lacks. Female $M$. scalaris are differentiated from closely related M. bistruncata and M. oxybelorum by broader T3 and T4 tergites compared to T5. Besides, yellowish abdominal tergites with short T6 tergite of $M$. scalaris differ from M. intermedia. In addition, $M$. scalaris possess variable sizes, and anterior scutellar bristles are often shorter than other relates species. The Neotropical and Nearctic M. imitatrix is apparently the most closely related species to $M$. scalaris $^{(12,26)}$. In Borgmeier's (1962) primary keys to Neotropical species, the male of $M$. pruinosifrons has a short anal tube and the anterior scutellars are minute hairs, instead of bristles. The female abdominal tergite 6 is not broader than T5, as is the case in M. scalaris (and M. imitatrix) $)^{(1,11)}$.

Table 4. Partial sequences of COI gene determined in the present study.

>COI_Partial_M. scalaris
GGGGCCTGAGCTGGAATAGTAGGAACATCTTTAAGTATTATAATTCGAGCTGAATTAGGGCACC
CTGGTGCTTTAATTGGTGATGATCAAATTTATAAAGAAATTGTTACTGCCCATGCATTTATTATAA
TTTTTTTATAGTAATACCTATTATAATAGGAGGATTTGGAAATTGATTAGTTCGCCTAATATTAG
GGGCACCTGATATGGCCTTTCCACGAATAAATAATATAAGTTTTGAATACTTCCCCCTTCTCTA
ACTCTTTTATTAGCAAGAAGTATAGTAGAAAATGGAGCTGGAACTGGTTGAACAGTTTATCCAC
CCCTATCTTCTAGAATTGCCCATAGAGGAGCTTCAGTCGATTTAGCAATTTTTCATTACATCTT
GCCGGAATTTCTTTATTCTTGGAGCAGTAAATTTTATTACTACAATTATTAATATACGATCCACA
GGAATTACTTTTGATCGAATACCTTTATTTGTATGATCAGTAGGTATTACTGCTCTTTTATTATACT
TTCACTACCTGTTCTAGCAGGTGCTATTACTATCTATTAACAGATCGAAATTTAATACATCATTC
TTTGACCCTGCAGGAGGGGGAGACCCCATTCTATATCAACATCTATT = $\mathbf{6 3 6 b p}$

Mitochondrial COI gene sequence is used as a genetic marker for identification of species $^{(27,28)}$. The region of COI amplified in the present study has about $98 \%$ sequence similarity with $M$. scalaris of previous literatures ${ }^{(29,30)}$. The use of $16 \mathrm{~S}$ rRNA has also been preferred in many cases as a marker in DNA taxonomy(13-33). About $93 \%$ sequence similarity has been found in case of $16 \mathrm{~S}$ rRNA gene fragment of the present specimen when aligned with $M$. scalaris of previous study ${ }^{(30)}$, though only $M$. scalaris sequences are the topmost BLAST hits (NCBI nucleotide BLAST). Since 16S rRNA sequence is more conserved than that of $\mathrm{COI}^{(34)}$, this discrepancy in the result might be due to sequencing artifacts. Nevertheless, it is not impossible that there are more variations in the 16S rRNA gene sequence among $M$. scalaris flies distributed in different regions of the world. So, further sequencing of the $16 \mathrm{~S}$ rRNA gene region of a sizable population of $M$. scalaris can be valuable in this circumstance.

The phylogenetic tree constructed using COI gene sequences of flies of different dipteran families indicates that the specimen is $M$. scalaris in conformity with morphological identification. M. scalaris is differentiated from other species belonging to dipteran families as found in previous studies ${ }^{(35,36)}$. Aschiza (Phoridae) and Schizophora 
Table 5. Blast search result

\begin{tabular}{|c|c|c|c|c|c|c|c|}
\hline & Description & $\begin{array}{l}\text { Max. } \\
\text { score }\end{array}$ & $\begin{array}{l}\text { Total } \\
\text { score }\end{array}$ & $\begin{array}{l}\text { Query } \\
\text { cover } \\
(\%)\end{array}$ & E value & $\begin{array}{l}\text { Iden- } \\
\text { tical } \\
(\%)\end{array}$ & Accession \\
\hline \multirow{6}{*}{$\begin{array}{l}\text { Blast Hits for } \\
\text { M. scalaris } \\
16 \mathrm{~S} \text { rRNA } \\
\text { gene }\end{array}$} & Megaseliascalaris mitochondrion, complete genome & 699 & 699 & 97 & 0.0 & 93 & KF974742.1 \\
\hline & Megaselia sp. A 16S ribosomal RNA gene, partial sequence & 682 & 682 & 97 & 0.0 & 92 & AF154806.1 \\
\hline & Megaselia sp. A 16S ribosomal RNA gene, partial sequence & 680 & 680 & 96 & 0.0 & 92 & AF154805.1 \\
\hline & Megaselia sp. A $16 \mathrm{~S}$ ribosomal RNA gene, partial sequence & 676 & 676 & 96 & 0.0 & 92 & AF154804.1 \\
\hline & Megaseliascalaris $16 \mathrm{~S}$ ribosomal RNA gene, partial sequence & 634 & 634 & 88 & $6 e-178$ & 93 & AF126340.1 \\
\hline & Megaselia sp. A 16S ribosomal RNA gene, partial sequence & 606 & 606 & 86 & $1 e-169$ & 92 & AF154807.1 \\
\hline \multirow{6}{*}{$\begin{array}{l}\text { Blast Hits for } \\
\text { M. scalaris } \\
\text { COI gene }\end{array}$} & Megaseliascalaris mitochondrion, complete genome & 1110 & 1110 & 100 & 0.0 & 98 & KF974742.1 \\
\hline & $\begin{array}{l}\text { Megaseliascalaris voucher RAMegsca- } 01 \text { cytochrome oxidase } \\
\text { subunit I (COXI) gene, partial }\end{array}$ & 1109 & 1109 & 99 & 0.0 & 98 & КT879896.1 \\
\hline & $\begin{array}{l}\text { Megaseliascalaris isolate } 01 \text { cytochrome oxidase subunit I } \\
\text { (COI) gene, partial }\end{array}$ & 1072 & 1072 & 100 & 0.0 & 97 & JQ941745.1 \\
\hline & $\begin{array}{l}\text { Megaseliascalaris mitochondrial COI gene for cytochrome } \\
\text { oxidase I, complete cds }\end{array}$ & 1061 & 1061 & 99 & 0.0 & 97 & AB907181.1 \\
\hline & $\begin{array}{l}\text { Megaseliascalaris voucher KOR-D17-001 cytochrome oxidase } \\
\text { I (COI) gene, partial cds }\end{array}$ & 1050 & 1050 & 100 & 0.0 & 96 & КС407773.1 \\
\hline & $\begin{array}{l}\text { Megaseliascalaris isolate HCORPTEH10 cytochrome oxidase } \\
\text { subunit I (COI) gene, partial cds }\end{array}$ & 981 & 981 & 93 & 0.0 & 96 & KU949579.1 \\
\hline
\end{tabular}


groups (Calliphoridae, Muscidae and Drosophilidae) are clearly distinguished. Members of the Schizophora occur together showing monophyletic origin and fit taxonomic classification of these dipteran species.

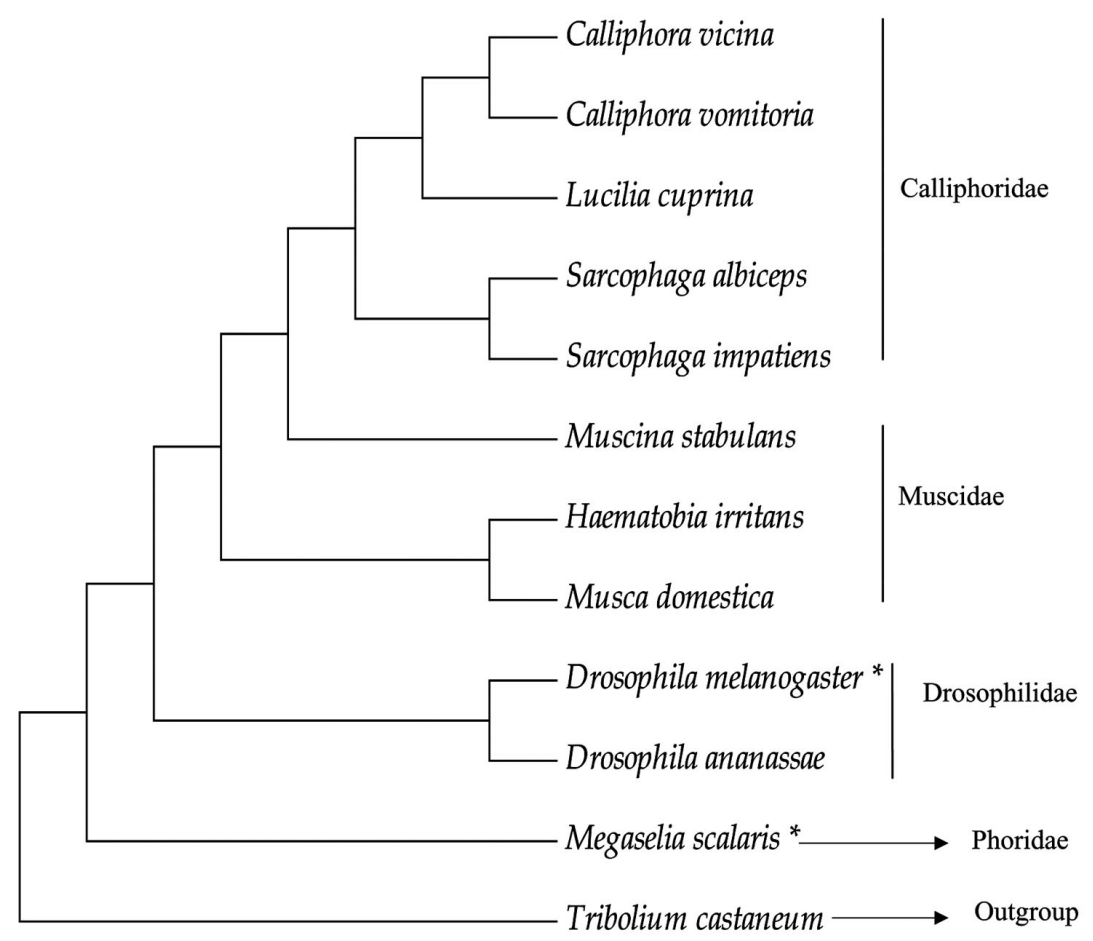

Fig. 4. Phylogenetic relationship among COI genes from different dipteran species. (NCBI accession numbers are given in Table 2, *Marked sequences were generated during this work).

In conclusion, this is the first report of Megaselia scalaris from Bangladesh. Morphological key has provided a clear identification of the species. Since, respective regions of COI and 16S rRNA genes of other species under genus Megaselia are not available in the sequence databases, molecular analysis alone could not be decisive about the species though it is a valuable addition for future such studies.

\section{Acknowledgments}

The authors like to thank Dr. R.H.L. Disney from the Department of Zoology, University of Cambridge, for his suggestion about the species identification. They also thank Mr. Faysal Mahmud, a former student of the Department of Zoology, University of Dhaka for taking images of Megaselia species. 


\section{References}

1. Borgmeier T 1968. A catalogue of the Phoridae of the world (Diptera : Phoridae). Studia Entomologica 11: 1-367.

2. Zwart P, RHL Disney, PD Batist and F Mutschmann 2005. The phorid scuttle fly (Megaselia scalaris) a threat to zoological collections and especially to amphibians. Zool. Med. BVZS. 5: $27-30$.

3. Peterson B 1987. Phoridae. Manual of Nearctic Diptera. Agriculture Canada Monograph. 28.

4. Disney RHL 2008. Natural history of the scuttle fly, Megaselia scalaris. Annual Review of Entomology 53(1): 39-60.

5. Costa J, CE Almeida, GM Esperança, N Morales, JRS Mallet, T Gonçalves and AP Prado 2007. First record of Megaselia scalaris (Loew) (Diptera: Phoridae) infesting laboratory colonies of Triatoma brasiliensis Neiva (Hemiptera: Reduviidae). Neotropical Entomology. 36(6): 987989.

6. Disney RHL 2002. Revisionary notes on European Phoridae (Diptera). Bonner Zoologische Beitrage. 50(4): 293-304.

7. Disney RHL 2009. Insects of Arabia scuttle flies (Diptera: Phoridae). Part II. the genus Megaselia. Fauna of Arabia 24: 249-357.

8. Thevan K, RHL Disney and AH Ahmad 2010. First records of two species of oriental scuttle flies (Diptera: Phoridae) from forensic cases. Forensic Science International 195(1-3): 5-7.

9. Varney RL and MA Noor 2010. The scuttle fly. Current Biology 20(11): 466-467.

10. Disney RHL and NP Ashmole 2004. Scuttle flies (Diptera: Phoridae) of the remote Atlantic islands of the Southern Hemisphere. Fragmenta Faunistica 47(2): 127-138.

11. Disney RHL, S Prescher and NP Ashmole 2009. Scuttle flies (Diptera: Phoridae) of the Canary Islands. J. Natural History. 44(3-4): 107-18.

12. Disney RHL and BJ Sinclair 2008. Some scuttle flies (Diptera: Phoridae) of the Galápagos Islands. Tijdschrift voor Entomologie. 151(1): 115-132.

13. Pereira F, J Carneiro and A Amorim 2008. Identification of species with DNA-based technology: current progress and challenges. Recent patents on DNA and gene sequences. 2(3): 187-200.

14. Rehbein H 2013. Differentiation of fish species by PCR-based DNA analysis of nuclear genes. European Food Research and Technology 236(6): 979-990.

15. Hajibabaei M, GA Singer, PD Hebert and DA Hickey 2007. DNA barcoding: How it complements taxonomy, molecular phylogenetics and population genetics. TRENDS in Genetics 23(4): 167-172.

16. Saccone C, C Giorgi, C Gissi, G Pesole and A Reyes 1999. Evolutionary genomics in Metazoa: The mitochondrial DNA as a model system. Gene 238(1): 195-209.

17. Cawthorn DM, HA Steinman and RC Witthuhn 2012. Evaluation of the $16 S$ and $12 S$ rRA genes as universal markers for the identification of commercial fish species in South Africa. Gene 491(1): 40-48.

18. Disney RHL and W Chou 1998. A new species of Megaselia (Diptera: Phoridae) reared from the fungus Pulveroboletus (Boletales: Boletaceae) in Taiwan. Bulletin of the National Museum of Natural Science, Taiwan 11: 135-139.

19. Doyle JJ and LL Doyle 1990. Isolation of DNA from small amounts of plant tissues. BRL focus. 12:13-15. 
20. Tamura K, G Stecher, D Peterson, A Filipski and S Kumar 2013. MEGA6: molecular evolutionary genetics analysis version 6.0. Molecular Biology and Evolution. 30(12): 27252729.

21. Gouy M, S Guindon and O Gascuel 2010. Sea View version 4: A multiplatform graphical user interface for sequence alignment and phylogenetic tree building. Molecular Biology and Evolution 27(2): 221-224.

22. Thompson JD, DG Higgins and TG Gibson 1994. CLUSTAL W : Improving the sensitivity of progressive multiple sequence alignment through sequence weighting, position-specific gap penalties and weight matrix choice. Nucleic Acids Research. 22(22): 4673-4680.

23. McLaughlin PJ and MO Dayhoff 1972. Evolution of species and proteins: A time scale. Atlas of protein sequence and structure 5: 47-52.

24. Saitou N and M Nei 1987. The neighbor-joining method: a new method for reconstructing phylogenetic trees. Molecular Biology and Evolution. 4(4): 406-425.

25. Koch NM, P Fontanarrosa, J Padró and IM Soto 2013. First record of Megaselia scalaris (Loew) (Diptera: Phoridae) infesting laboratory stocks of Mantids (Parastagmatoptera tessellata, Saussure). Arthropods 2(1): 1.

26. Disney RHL 1989. Scuttle flies (Diptera: Phoridae) genus Megaselia. Royal Entomological Society. 10(8).

27. Hebert PD, A Cywinska and SL Ball 2003. Biological identifications through DNA barcodes. Proceedings of the Royal Society of London B: Biological Sciences. 270(2003): 313-321.

28. Hogg ID and PD Hebert 2004. Biological identification of springtails (Hexapoda: Collembola) from the Canadian Arctic, using mitochondrial DNA barcodes. Canadian Journal of Zoology 82(5): 749-754.

29. Boehme P, J Amendt, RHL Disney and R Zehner 2010. Molecular identification of carrionbreeding scuttle flies (Diptera: Phoridae) using COI barcodes. International Journal of Legal Medicine 124(6): 577-581.

30. Zhong, M, X Wang, Q Liu, B Luo, C Wu and J Wen 2016. The complete mitochondrial genome of the scuttle fly, Megaselia scalaris (Diptera: Phoridae). Mitochondrial DNA. 27(1): 182-184.

31. Collins AG, S Winkelmann, H Hadrys and B Schierwater 2005. Phylogeny of Capitata and Corynidae (Cnidaria, Hydrozoa) in light of mitochondrial $16 S \mathrm{rDNA}$ data. Zoologica Scripta 34(1): 91-99.

32. Steinke D, C Albrecht and M Pfenninger 2004. Molecular phylogeny and character evolution in the Western Palaearctic Helicidae sl (Gastropoda: Stylommatophora). Molecular phylogenetics and Evolution 32(3): 724-734.

33. Mathews LM, CD Schubart, JE Neigel and DL Felder 2002. Genetic, ecological, and behavioural divergence between two sibling snapping shrimp species (Crustacea: Decapoda: Alpheus). Molecular Ecology 11(8):1427-1437.

34. Xia Y, H Gu, R Peng, Q Chen, Y Zheng, RW Murphy and X Zeng 2012. COI is better than $16 \mathrm{~S}$ rRNA for DNA barcoding Asiatic salamanders (Amphibia: Caudata: Hynobiidae). Molecular Ecology Resources 12(1): 48-56.

35. Weinmann D and RHL Disney 1997. Two new species of Phoridae (Diptera) whose larvae associate with large spiders (Araneae: Theraphosidae). Journal of Zoology 243(2): 319-328.

36. Serna E 2004. The gene sex-lethal of the Sciaridae family (Order Diptera, Suborder Nematocera) and its phylogeny in Dipteran insects. Genetics 168(2): 907-921. 